\title{
Reforma Protestante, 500 anos: ensaio de crítica histórica
}

\author{
Protestant Reformation, 500 years: essay of historical criticism
}

\section{Ronaldo Cavalcante*}

Faculdade Unida de Vitória, Vitória, ES, Brasil

\section{Resumo}

Após a Reforma do século XVI, o fenômeno religioso protestante começou a se formar e estava diretamente conectado com a cultura circundante. Nessa formação, buscou primeiramente pautar sua identidade de forma apologética em contraposição ao catolicismo por meio de diatribes, catecismos, declarações e confissões de fé. A luta doutrinária se mesclava com as estratégias políticas com enormes repercussões também na economia e no cotidiano da vida pública e privada. Após a primeira geração, já no século XVII, surgiriam outros desafios e objetivos que ajudaram a forjar um estilo próprio de se vivenciar o cristianismo em diálogo com os novos tempos. A modernidade demandou novos posicionamentos religiosos e éticos. Juntamente com setores progressistas do catolicismo e da sociedade em geral, o ethos protestante participou na fixação de valores que resultaram em conquistas importantes para a gênese das

\footnotetext{
RC: Doutor em Teologia Dogmática, e-mail: ronaldopcavalcante@yahoo.com.br
} 
sociedades modernas. As novas possibilidades da teologia protestante, que agora se abria ao diálogo com o mundo das letras e da ciência, produziu um enorme contingente de novos personagens em diversas áreas do conhecimento que foram fundamentais em questões como a nova educação, a superação da escravidão, melhora das condições laborais, ecumenismo etc. O protestantismo, não obstante seus muitos equívocos, tornou-se uma alternativa legítima dentro do cristianismo.

Palavras-chave: Reforma. Protestantismo. Modernidade. Ecumenismo.

\section{Abstract}

After the protestant reformation a religious phenomenon was being built directly connected to the surrounding culture. The identity of this phenomenon was apologetic and guided firstly in opposition to Catholicism through diatribes, catechisms, declarations and confessions of Faith. The Doctrinal struggle merged with the political strategies sent huge shockwaves through the economy and the daily life of public and private life. After the first generation - already in the seventeenth century - there would be other challenges and objectives that helped to forge a style of experiencing Christianity in dialogue with the new times. Modernity has demanded new religious and ethical positions. Together with progressive sectors of Catholicism and society at large, the Protestant ethos participated in setting values that resulted in important achievements for the genesis of modern societies. The new possibilities of Protestant theology, which was then open to dialogue with the world of letters and science, produced an enormous contingent of new characters in several areas of knowledge that were fundamental in issues such as new education, overcoming slavery, improvement of working conditions, ecumenism etc. Protestantism, despite its many misconceptions, has become a legitimate alternative within Christianity.

Keywords: Reformation. Protestantism. Modernity. Ecumenism. 


\section{Introdução}

A avaliação ou mesmo a descrição de um fenômeno religioso marcado por instabilidade, é sempre complexo. Ademais, com frequência, a descrição da experiência protestante por pesquisa interna corporis - realizada por sujeitos ligados ao grupo religioso - sem o necessário distanciamento e rigor científicos que o objeto exige, resulta em mitificações de fatos e personagens que desconsideram os processos humanos normais. Em geral, o produto final não é satisfatório. Ainda assim, arriscamos!

Passados cinco séculos de estudos e pesquisas, há segurança ao afirmar que a Reforma Protestante, em perspectiva cultural, com tudo o que isso pode significar, foi um acontecimento chave para a sociedade ocidental $^{1}$. Pode ser catalogado naquele conjunto de fatos sociais que implicaram em mudança de paradigma na história. Na verdade, a Reforma tornou-se relevante apenas com o passar dos anos, incorporando-se à vida pública e privada como um continuum significante axiológico, alterando permanentemente a identidade social do Ocidente. Este, seguiu sendo cristão, porém, serviu de receptáculo para outros formatos de cristianismo com novos conteúdos e distintas consequências sociais. Grande parte daquilo que é afirmado recorrentemente hoje como sendo a essência da Reforma - as correções doutrinárias do medievo foi, de fato, uma realidade apenas da primeira geração protestante. A redução da Reforma ao espectro doutrinário entendendo-o como uma ação de ortodoxia cristã dirigida diretamente por Deus, apenas confunde e ilude os espíritos, uma

1 Acerca disso, ver: WHITEHEAD, N. A. A ciência e o mundo moderno. São Paulo: Paulus, p. 21, 2006; RAWLS, J. O liberalismo político. Brasília: Inst. Teotônio Vilela e Ed. Ática, p. 30, 2000; BAUMAN, Z. Em busca da política. Rio de Janeiro: Zahar, p. 160, 2000; GELLNER, E. Condições da liberdade: A sociedade civil e seus rivais. Rio de Janeiro: Jorge Zahar, p. 46, 1996; WALZER, M. Las esferas de la justicia: Una defensa del pluralismo y la igualdad. México: FCE, p. 255, 1997; TAYLOR, C. As fontes do self: A construção da identidade moderna. São Paulo: Loyola, p. 296, 2013; Bobbio, N. Liberalismo e democracia. São Paulo: Brasiliense, p. 50, 2005; HABERMAS, J. In: Eduardo Mendieta e Jonathan Vanantwerpen (Eds.). El poder de la religión en la esfera pública. Madrid: Editorial Trotta, p. 28, 2011. Ainda sobre o significado da Reforma, ver: OBERMAN, A. H. The impact of the reformation. Grand Rapids-MI-USA: Wm. B. Eerdmans Publishing Co., 1994. Sobre Lutero, desse mesmo autor: OBERMAN, A. H. Luther: man beteween God and the Devil. New Haven: Yale University Press, 1989. 
vez que alimenta o agigantamento de ideias e personagens, não fazendo justiça à sua humanidade inerente e aos interesses envolvidos. A Reforma e a consequente performance do protestantismo ${ }^{2}$, como seu produto natural, significaram a presença de uma religiosidade imersa no mundo da cultura e no cotidiano das pessoas em seus afazeres laborais, alterando permanentemente a rota dos indivíduos. As teses de Max Weber, acerca do fenômeno protestante ocidental, após mais de um século, não obstante as eventuais limitações ${ }^{3}$, continuam sendo, no mínimo, interessantes.

Mas como se diz, 500 anos é bem mais que 5 anos! Os fatos são conhecidos - a gênese do protestantismo compõe-se de alguns elementos fundantes: (i) em 31 de outubro de 1517 em Wittenberg (Região da Saxônia), na Alemanha, dá-se o protesto público e escrito, (em Latim), do monge agostiniano Martin Luther (1483-1546) contra a venda das indulgências - as 95 teses; (ii) nos dois anos seguintes, Lutero ignorou uma intimação do Papa para apresentar-se em Roma, porém, aceitou ser interrogado pelo Cardeal Cajetano (1469-1534) na cidade de Augsburg (1518) e posteriormente participou nos debates teológicos de Heidelberg (1518) e Leipzig (1519), disputando com Johannes Brenz (1499-1570), Martin Butzer (1491-1551) e Johannes Eck (1483-1543), respectivamente; (iii) em 1520, Lutero produziu seus primeiros escritos teológicos ${ }^{4}$, dentre eles destaco: Do cativeiro babilônico da igreja e Da liberdade de um cristão; (iv) em decorrência, a Universidade de Wittenberg, onde Lutero ensinava, recebeu a Bula de Excomunhão - Exsurge Domine - que em dezembro foi queimada em ato público por Lutero; (v) tais fatos convergiram para a pauta de assuntos da Dieta de Worms (1521), perante o Imperador Carlos V. Ao não se retratar, apelando à Bíblia e à consciência, Lutero foi proscrito do Império e poderia ser preso ou morto, no entanto, esteve protegido pelo eleitor da Saxônia, Frederico, o Sábio, e levado em segurança para o castelo de Wartburg, "sob o nome de cavaleiro Georges"; (vi) Nesse mesmo ano,

2 Em Português, sobre o protestantismo em um sentido abrangente, ver: MCGRATH, A. A revolução protestante. Brasília: Editora Palavra, 2012.

3 Ver a propósito: COLLINSON, P. A reforma. Rio de Janeiro: Objetiva, p. 231-142, 2006.

4 Ver: LUTERO, M. Obras Selecionadas, Vol. 2. 0 Programa da Reforma: Escritos de 1520. São Leopoldo/Porto Alegre: Editora Sinodal e Concórdia Editora, 1989.

5 DELUMEAU, J. Nascimento e afirmação da reforma. São Paulo: Pioneira, p. 98, 1989. 
Lutero iniciou a tradução do Novo Testamento para o Alemão, finalizando-a em 10 meses, com publicação em 1522. Até o final dos anos 20, a produção intelectual de Lutero foi ampla e variada ${ }^{6}$ : tratados, hinos, comunicados, cartas, comentários bíblicos, homilias etc. Com destaque para os Catecismos Menor e Maior ${ }^{7}$ que foram denominados de "Bíblia dos leigos", por conterem tudo aquilo que era necessário para a salvação.

Após esta descrição sintética dos movimentos iniciais e na tentativa de lograr um melhor esquadrinhamento, ainda que nos limites do presente artigo, sugiro a seguinte clivagem do fenômeno protestante: 1) A Formação da Identidade Plural Protestante (1523-1647); 2) Solidificação, Expansão e Abertura do Fenômeno Protestante (1648-1918); 3) Nova Teologia Protestante e Ecumenismo (1919-1953).

\section{A Formação da Identidade Plural Protestante (1523-1647)}

Bem cedo, surgiram outros líderes que dividiriam com Lutero o peso dessa nova alternativa cristã no Ocidente. Destaco aqui apenas os mais relevantes para o desenvolvimento ulterior do protestantismo: a) Philipp Melanchthon (1497-1560), teve sua formação em Pforzheim, Heidelberg e Tübingen. Foi nomeado professor de grego clássico na universidade de Wittenberg, desde 1518, onde conheceu Lutero, sendo influenciado diretamente por ele. Em 1521 publicou seu Loci theologici,

6 Destaco aqui as que julgo mais importantes: Da autoridade secular, até que ponto se lhe deve obediência (1523); Aos conselhos de todas as cidades da Alemanha, para que criem e mantenham escolas (1524); Contra as hordas salteadoras e assassinas dos camponeses (1525); Da vontade cativa (1525); 0 manual do batismo traduzidos para o alemão revisado (1526); Hino Ein feste Burg ist unser Gott (1527); Da Santa Ceia de Cristo - Confissão (1528); Catecismos Menor e Maior (1529); Prédica para que se mandem os filhos à escola (1530).

7 Utilizo a versão brasileira: Martinho Lutero. Os catecismos. Porto Alegre/São Leopoldo: Concórdia/Sinodal, 1983. Ambos catecismos estão prefaciados pelo próprio Lutero. 0 Catecismo Menor foi chamado por Lutero de Enchiridion. Trata-se de um texto bem resumido, contendo sete seções: o Decálogo; o Credo; o PaiNosso; o Sacramento do Santo Batismo; a Confissão; o Sacramento do Altar; Orações. 0 Catecismo Maior - Deustsch Katechismus, com o mesmo conteúdo, porém, bem mais extenso e complexo e redigido como comentário de forma contínua.

8 Loci Communes Theologici é a primeira obra protestante quase no formato de uma teologia sistemática ou dogmática como conhecemos atualmente; uma verdadeira apologia das posições luteranas, organizando as matérias, com destaque para o pecado, a lei e a graça. 
obra magistral, na qual expõe os temas, "lugares" fundamentais da teologia. Além da teologia (comentários bíblicos, liturgia etc.), Melanchthon destacouse como um educador humanista, influência recebida em Pforzheim de Johannes Reuchlin, (1455-1522) e de Erasmo de Roterdã (1466-1536). Como tal, empreendeu importantes reformas curriculares em várias universidades alemãs e foi também incansável nos esforços ecumênicos, com abertura para a mudança doutrinária em pontos não essenciais da fé em prol da unidade cristã. b) Ulrich Zwingli (1484-1531), suíço, bastante influenciado por Lutero, mas também pelo humanismo erasmiano. Teve sua formação em Berna, Viena e Basel, posteriormente, teve uma presença bem ativa como sacerdote primeiramente em Einsiedein (1506 a 1518) e em Zurich (1519-1531). Nessa cidade, como fruto do debate público com os católicos em 1523, produziu os

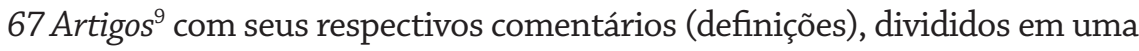
estrutura temática. Os 67 Artigos são considerados o primeiro documento confessional do protestantismo, ainda que restrito às igrejas reformadas da Suíça de fala alemã. Pelos temas percebe-se o clima animoso entre católicos e protestantes, a alta temperatura das tensas relações entre as duas confissões. c) Menno Simons (1496-1561) talvez o mais destacado líder do movimento anabatista ${ }^{10}$. Sacerdote holandês, por dúvidas quanto o batismo de crianças e a transubstanciação, Simons abandonou o catolicismo em 1536 e em pouco tempo tornou-se líder anabatista, produziu muitos tratados nos quais defendeu o pacifismo cristão e em favor de um cristianismo mais simples. Nesse sentido está seu principal trabalho escrito: O Fundamento da Doutrina Cristã, no qual faz uma apologia do anabatismo, conclamando as autoridades

9 Os temas dos 67 Artigos de Zwínglio: Vom Papst - Do Papa, Von der Messe - Da Missa, Von der Fürbitte der Heiligen - Da Intercessão dos Santos, Von den guten Werken - Das Boas Obras, Vom Gut der Geistlichen - Da Propriedade Clerical, Vom Speiseverbot - Das Comidas Proibidas, Von Feiertagen und Wallfahrten - Dos Feriados e Peregrinações, Von Kutten, Kleidung, Abzeichen - De Túnicas, Vestes, Insígnias, Von Orden und Sekten - Da Ordem do Culto, Von der Ehe der Geistlichen - Do Casamento dos Sacerdotes, Vom Gelübde der Keuschheit Do Voto de Castidade, Von dem Bann - Da Proibição, Von unrechtmäßigem Gut - Da Propriedade Ilegal, Von der Obrigkeit - Das Autoridades, Vom Gebet - Da Oração, Vom Ärgernisgeben - Da Ofensa, Vom Vergeben der Sünde - Do Perdão do Pecado, Vom Fegfeuer - Do Purgatório, Von der Priesterschaft - Do Secerdócio, Vom Abstellen von Mißbräuchen - Da Interrupção dos Abusos. Em Português, disponivel em: <http://www.e-cristianismo.com. $\mathrm{br} /$ historia-do-cristianismo/outros-reformadores/os-67-artigos-de-zuinglio.html>.

${ }_{10}$ Talvez reformador radical menos conhecido do público brasileiro. Dados sobre sua vida, obra e pensamento podem ser vistos na esclarecedora síntese: GEORGE, T. Teologia dos reformadores. São Paulo: Vida Nova, 1994, p. 251 a 304 com bibliografia selecionada.

Rev. Pistis Prax., Teol. Pastor., Curitiba, v. 9, n. 2, 441-463, maio/ago. 2017 
civis e religiosas à tolerância, uma vez que a expressão de fé e prática anabatista sofria perseguição de todos os lados. Outros reformadores alemães e suíços são: d) Wolfgang Capito (1478-1541), e) Johannes Ecolampádio (1482-1531), f) Nicolau von Amsdorf (1483-1565), g) Georg Spalatin (1484-1545), h) Thomaz Müntzer (1488-1525), i) Martin Butzer (1491-1551), j) Justus Jonas (1493-1555) k) Andreas Osiander (1498-1552), 1) Johann Heinrich Bullinger (1504-1575).

Simultaneamente, na Suiça de fala francesa, um forte movimento reformista se desenvolvia. m) Jean Calvin ${ }^{11}$ (1509-1564) era seu principal líder. Francês, com sólida formação humanista em Filosofia e Direito, precedido por n) Guilaume Farel (1489-1565) e o) Theodor Beza (15191605) que o sucedeu em Genebra. Sua magnum opus, Christianae religionis institutio (Institutas da religião cristã) ${ }^{12}$ em quatro volumes, com a primeira edição em 1536 e a última em 1559 em Latim e em Francês (1560), já bem ampliada e corrigida, tornou-se um importantíssimo manual para a leitura das Escrituras. Além dessa obra, Calvino produziu escritos litúrgicos e catequéticos, tratados, panfletos, cartas, sermões, comentários de quase toda a Bíblia. Em 1541, quando regressou a Genebra, após seu exílio em Strasbourg (1538-1541), organizou para a cidade, Les Ordonnances Ecclésiastiques $^{13}$, contemplando os seguintes ofícios: Les Pasteurs, Les Docteurs, Les Anciens, Les Diacres. Elaborou, nesse mesmo período, o Catéchisme de l'Église de Genève ${ }^{14}$ em Francês (1542) e Latim (1545), especialmente dedicado à instrução das crianças. Um de seus discípulos mais importantes foi p) John Knox (1514-1572), teólogo escocês que, após estar em Genebra, voltou à Escócia levando as sementes reformistas, porém, dentro de um distinto modelo de governo eclesiástico, o presbiterianismo. Na Holanda, q) Jacobus Armínius (1560-1609), se notabilizou por discordar da corrente calvinista tradicional presente em seu país, em especial a

${ }^{11}$ Sobre vida, obra e pensamento de Calvino, em Português, ver: McGRATH, A. A vida de João Calvino. São Paulo: Cultura Cristã, 2004.

12 Em Português: CALVINO, J. A instituição da religião cristã. I e II. São Paulo: UNESP, 2008/2009.

${ }^{13}$ As Ordenanças Eclesiásticas eram parte de uma nova ordem civil e religiosa instituída por Calvino para a cidade de Genebra.

${ }^{14}$ Catecismo de lgreja de Genebra - Documento contendo as principais doutrinas cristãs, esquematicamente montado para ser lido nas 55 semanas do ano. 
doutrina da predestinação; sua influência foi enorme, porém, suas posições teológicas foram condenadas no Sínodo de Dortrecht em 1618-1619, quando aconteceu um visível endurecimento doutrinário com a elaboração dos denominados cinco pontos do calvinismo ${ }^{15}$. Assim, a Holanda conseguiu conviver com duas tradições reformadas, uma radicalizando a tradição calvinista de Genebra e outra mais ligada às interpretações de Armínius e que foram preservadas e veiculadas pela Academia de Saumur na França e também ligada ao pensamento teológico de Moisés Amyraut (1596-1664). Com essa variedade de personagens, produziram-se inúmeros documentos confessionais nos respectivos países aderentes da Reforma. Mencionamos aqui apenas os mais importantes:

Em 1530 os luteranos produziram a) Confessio Augustana ${ }^{16}$, documento seminal da féluterana redigido e apresentado por Melanchthon em Augsburg, perante o Imperador que em suas intenções primárias tinha objetivos político-militares em relação aos turcos. $\mathrm{Na}$ agenda da reunião em Augsburgo, o tema teológico não era o mais importante, mas ganhou destaque pois sinalizava a situação quanto à unidade do império. O fosso entre católicos e protestantes estava cavado e crescia em extensão e profundidade. A confissão de Augsburgo explicitou de forma definitiva, as diferenças com o catolicismo e solidificou de vez a identidade luteranoprotestante. Em 1531, diante da refutação da Confissão pelos teólogos católicos, sob a liderança de Eck, Melanchthon redigiu a b) Die Apologie der Confessio Augustana ${ }^{17}$. Contudo, em 1537, aconteceu na cidade de Smalkalde, na Alemanha, uma possibilidade insólita de diálogo entre católicos e luteranos, quando estes foram convidados pelo Papa Paulo III a estarem presentes. Havia questões não controversas e questões ainda

${ }^{15}$ TULIP - É um acróstico que forma o nome em Inglês da flor mais conhecida da Holanda e que se refere à síntese das decisões teológicas tomadas no Sínodo de Dort: 1. Total Depravity; 2. Unconditional Election; 3. Limited Atonement; 4. Irresistible Grace; Perseverance of the Saints.

${ }^{16}$ Confissão de Augsburgo - Das Augsburger Bekenntnis. Edição bilíngue. (Trad.: Arnaldo Schüler). São Leopoldo: Sinodal, 1980. Seu conteúdo está exposto em 28 artigos divididos em duas grandes seções: Artigos principais da Fé e Artigos em que se recenseiam os abusos mudados. Esta edição está precedida de uma esclarecedora introdução escrita pelo professor Martin Dreher. Ver ainda: BECK, L. et alii.. Confissão da Esperança: Exposição histórica e doutrinária da Confissão de Augsburgo. (Trad.: Arnaldo Schüler). Porto Alegre: Concórdia, 1980.

${ }^{17}$ Em Português: Melanchthon, F. Apologia da Confissão de Augsbugo. Porto Alegre: Concórdia, 1969. 
abertas como a exclusividade da obra justificadora de Cristo. O texto foi preparado do Lutero e transformou-se nos c) Schmalkaldische Artikel ${ }^{18}$ publicados em 1538 e posteriormente incluídos no Livro da Concórdia (1577) contendo todos os principais símbolos de fé luteranos no intuito de mitigar as diferenças internas após a morte de Lutero. Finalmente, em 1580 foi produzido o d) Das Konkordienbuch ${ }^{19}$, composto pelos Credos: Apostólico, Niceno e Atanasiano; a Confissão de Augsburg, a Apologia da Confissão de Augsburg; os Catecismos Menor e Maior; os Artigos de Smalkalde; o Tratado sobre o Poder do Papa e a Fórmula da Concórdia. Este é o conjunto documental que define a fé Luterana, até os dias de hoje.

Entrementes, na Inglaterra, produziu-se o documento central da Church of England ${ }^{20}$ : a) The Thirty-nine Articles of Religion ${ }^{21}$, que foram estabelecidos em 1563 e finalizados em 1571 mediante a adesão aos mesmos pelo Parliament como uma lei, após inúmeras revisões, sendo incorporados ao b) Book of Common Prayer (1549), sob os auspícios do Arcebispo de Canterbury, Thomas Cranmer (1489-1556). Ambos os documentos objetivavam posicionar a Igreja da Inglaterra diante do Catolicismo e dos demais grupos protestantes, com a intenção de ser uma via media para o cristianismo moderno. Liturgicamente e em seu sistema de governo, o anglicanismo é um claro herdeiro do catolicismo, porém, em sua teologia sobressaem as intepretações luteranas ou calvinistas clássicas.

Na segunda metade do século XVI, o lado calvinista da Reforma, foi igualmente pródigo na produção de documentos confessionais ${ }^{22}$. Além dos escritos de Calvino, já aludidos, a tradição calvinista esmerouse na publicação de confissões de fé e catecismos. Menciono, igualmente, os mais significativos com vistas a formação da identidade reformada: a) The Scot's Confession ${ }^{23}$, de 1560, foi produzida por seis líderes da igreja na Escócia, entre eles o já mencionado, John Knox. Firmemente alicerçada no

${ }^{18}$ Escritos por Lutero no final de 1536 e apresentados no ano seguinte aos líderes protestantes.

19 Em Português: Livro de Concórdia. São Leopoldo/Porto Alegre: Sinodal/Concórdia, 2006.

20 Acerca do Anglicanismo, ver sobretudo, o clássico: Stephen Neill. El anglicanismo. Madrid: IERE, 1986. Com farta bibliografia.

${ }^{21}$ Os XXXIX Artigos de Religião. In: <http://mb-soft.com/believe/ttcm/thirtyni.htm>.

22 Ver: The Book of Confessions. New York: The United Presbyterian Church in The USA, 1970; Confesiones de Fé da la Iglesia. Barcelona: Literatura Evangelica, 1990.

${ }^{23}$ A Confissão de Fé Escocesa. In: <http://crco.com.br/downloads/credos/17.pdf>. 
pensamento teológico de Calvino, permaneceu por cerca de 80 anos como a exposição oficial da Igreja Escocesa, até ser substituída pela Confissão de Westminster. b) La Confession de Foi Belge $e^{24}$, escrita em Francês por Guy de Bray (1522-1567) em 1561, buscava uma diferenciação com os segmentos anabatistas, contendo 37 artigos. c) Confessio Helvetica posterior ${ }^{25}$, foi escrita em Latim por Heinrich Bullinger (1504-1575) em 1562 e 1566 em Alemão, sendo adotada por igrejas reformadas em diversos países. d) Der Heidelberger Katechismus ${ }^{26}$, foi elaborado em 1563 por dois professores da Universidade de Heidelberg, Zacharias Baer (Ursinus) (1534-1583) e Caspar Olevian (1536-1587). Estava redigido na forma de perguntas e respostas, num total de 128 . A pergunta de número 80 era uma clara reação aos decretos do Concílio de Trento, sendo amplamente utilizado, em sua versão holandesa, nos Países-baixos. e) Synode van Dordrecht ${ }^{27}$ (1618-1619), na Holanda acerca da polêmica entre calvinismo e arminianismo, com a vitória daquele e a afirmação dos cinco pontos do calvinismo, conforme vimos, nota 8. f) The Westminster Confession of Faith ${ }^{28}$, composta em 1647, é considerada no mundo reformado como a mais completa e perfeita confissão de Fé, tendo sido escrita com o propósito de reorganizar a Igreja da Inglaterra com base na compreensão puritana da fé cristã. Sua influência é ainda imensa no protestantismo reformado, a ponto de a ordenação de ministros estar condicionada à sua aceitação.

\section{Solidificação, Expansão e Abertura do Fenômeno Protestante (1648-1918)}

Nos quase três séculos, após as "Guerras de Religião" e a "Guerra dos Trinta Anos", isto é, da Paz de Westfália (1648) até o final da Primeira Guerra Mundial (1918), o protestantismo experimentou uma evolução

\footnotetext{
${ }^{24}$ A Confissão de Fé Belga. Disponível em: <http://www.crco.com.br/downloads/credos/14.pdf>.

${ }^{25}$ Segunda Confissão Helvética. Disponível em: <http://www.monergismo.com/textos/credos/seg-confissaohelvetica.pdf>.

${ }^{26} 0$ Catecismo de Heidelberg. Disponivel em: <http://mb-soft.com/believe/tth/heidtext.htm>.

${ }^{27}$ Os Cânones de Dort. Disponível em: <http://reforma500.com.br/wp-content/uploads/2016/10/0sC\%C3\%A2nones-de-Dort.pdf>.

${ }^{28}$ A Confissão de Fé de Westminster. (Texto integral). São Paulo: Editora Cultura Cristã, 1994.
} 
singular, desde a alvorada da modernidade no século XVII, com o advento da Scientia moderna, passando pela eclosão do Iluminismo e da Revolução Industrial. O ano de 1648 é, de fato, uma data emblemática, pois ratificou, em contexto luterano, as decisões do Tratado de Augsburg (1555), contemplando o calvinismo e garantindo a católicos e protestantes a liberdade de culto. Contudo, o caráter sólido do discurso protestante, decorrente de sua fixação doutrinária estampada nas eloquentes sínteses: Sola gratia, Sola fides, Sola scriptura e Solus Christus e reafirmadas em doutrinas como a da "justificação pela fé somente", por meio da fórmula simul iustus et peccator, da "Dupla predestinação", e do "Sacerdócio universal dos cristãos", teria que conviver com a instabilidade e inovações das livres interpretações por não ter o benefício de uma instância autoritativa e decisória final; e com isso, a "túnica inconsútil" 29 de Cristo transformou-se numa "colcha de retalhos", com um sem números de emendas e cada vez mais multicolorida à medida que se expandia geográfica e confessionalmente em uma espécie de progressão geométrica (1, 2, 4, 8, 16, 32, 64, 128, 256, 512, 1024...). Entretanto, não é forçoso lembrar que na teoria malthusiana, havia um alerta preocupante diante da futura escassez de alimentos para a população crescente. Ademais, o caráter fragmentário do protestantismo evidenciava não apenas a preponderância do indivíduo em sua autonomia e liberdade, como destacou Hegel:

Já que o indivíduo agora sabe que está plenificado com o espírito divino, ficam suprimidas todas as relações da exterioridade: não existe mais diferença entre sacerdote e leigo, não há mais uma classe que detenha exclusivamente o conteúdo da verdade[...] Este é o conteúdo essencial da Reforma: o homem está determinado por si mesmo a ser livre ${ }^{30}$.

${ }^{29}$ Se a Reforma Protestante foi a quebra da síntese e a mácula na túnica inconsútil de Cristo, como pensava a apologética católica, a fragmentação social moderna foi acompanhada por uma avalanche de religiosidades protestantes, cada qual com sua doutrinação, foi a transformação da túnica em trapos. Falando a partir da fé, nada é mais horrendo que o divisionismo com base na vaidade humana e na ideologia de gueto encobertas pelo discurso da fidelidade à sã doutrina. Se o pontificado católico era, nas palavras do próprio Paulo VI, um grande obstáculo à unidade exatamente porque cria ter a posse da verdade toda, o divisionismo protestante foi uma nódoa na túnica antes de ela ser feita em mil pedaços.

30 HEGEL, G. W. F. Filosofia da história. Brasília: Editora UNB, p. 345-346, 2008. 
Mas, também as interpelações redutoras e individualistas, manifestas no galopante divisionismo interno e na atomização religiosa descontrolada com uma acentuada perda do princípio da unidade orgânica do rebanho (Una Sancta), preconizada no Evangelho e nas parêneses paulinas, em detrimento da legitimação do seu contrário. Portanto, fixouse não a unidade em meio à diversidade como o proprium do kerigma cristão, e sim, o personalismo carismático, por um lado e o centralismo dogmático, por outro; ambos ensimesmados da verdade, seja em sua vertente "mágica" com base em um experimentalismo afoito ou em sua versão racional presente nas fórmulas doutrinárias fechadas - acabouse o mistério da fé! Reproduz-se em solo religioso protestante tanto o empirismo como o racionalismo como instrumentos de conhecimento religioso.

Paradoxalmente, deu-se uma abertura, precisamente na inserção e contribuição da abordagem protestante na nova configuração do mundo ocidental — as novas invenções manifestas na imprensa, na navegação, na astronomia, no transporte, no trabalho, no cotidiano etc., como também no mundo do pensamento universitário e acadêmico, com o surgimento dos novos modelos educacionais. Os avanços sociais ${ }^{31}$, científicos $^{32}$ e político-econômicos ${ }^{33}$, em muitos momentos, significaram um desconforto para as crenças e dogmas cristãos, sendo que, na sequência, o protestantismo, em linhas gerais, absorveu a crítica moderna da religião alterando seu discurso teológico, adequando-se às novas descobertas, inclusive refazendo sua leitura e interpretação dos escritos sagrados, com repercussão imediata em seu corpus doutrinário, ocasionando, por um lado, a insegurança para o ambiente eclesial, e por outro, o início do diálogo com a vanguarda do pensamento iluminista, produzindo uma pensamento teológico aberto, liberal, desde o final do século XVII, com pensadores como John Toland (1670-1722) e Matthew Tindal (1657-1733) ${ }^{34}$ que

${ }^{31}$ Como no caso do crescente papel da mulher no mundo das letras ou mesmo, a luta explícita contra o sistema escravagista.

${ }^{32}$ A reação religiosa inicial contra a teoria heliocêntrica, ou mais tarde, diante da teoria evolucionista.

${ }^{33}$ A derrocada do feudalismo e a ascensão de uma burguesia mercantil indinheirada, socialmente ascendente.

${ }^{34}$ TOLAND, J. Christianity not mysterius. Dublin: The Liliput Press, 1997 (1696); e TINDAL, Matthew. Christianity as Old as the Creation: or the gospel a republication of the religion of nature. Lexington-KY-USA: Forgotten Books, 2016 (1730, 1798). Ambas obras sem tradução para o Português.

Rev. Pistis Prax., Teol. Pastor., Curitiba, v. 9, n. 2, 441-463, maio/ago. 2017 
abririam o caminho para uma nova forma de religião cristã que acolhia especialmente intelectuais e membros não praticantes do anglicanismo, bem como, livres pensadores que certamente desacreditavam na doutrina da revelação e em várias outras, era o deísmo cristão, uma tentativa de se conjugar o cristianismo com as descobertas científicas e o progresso da modernidade; para tanto, dava-se uma interpretação naturalista à fé cristã, retirando dela qualquer doutrina ou fato não comprovável pela ciência. Mantinha-se Deus como criador do universo, mas não mais com ações de interferências no mundo dos homens. $\mathrm{O}$ aspecto moral do cristianismo tornava-se a mensagem por excelência a ser veiculada. Tal ideia influenciaria na própria visão religiosa de I. Kant. O deísmo foi uma forma encontrada na Inglaterra, que depois se espalhou na Europa, como forma de não descartar a religião, uma vez que ela era parte integrante da própria identidade britânica. Esta versão "liberal" da teologia desenvolveu-se sobremaneira nos séculos XVIII e XIX, em especial com o uso do método histórico-crítico, alcançando seu ápice em teólogos como F. Schleiermacher (1768-1834) e A. Ritschl (1822-1889), culminando com A. von Harnack (1851-1930). A teologia protestante liberal, não obstante seus méritos na persecução criteriosa da verdade das origens cristãs (incluindo, não apenas a literatura do Novo Testamento, senão, todo o imenso patrimônio cultural-literário do Antigo Testamento), legou ao século XX um mar de verdades desconfortáveis, de um lado e, de outro, incertezas mil; em um contexto assim, dificilmente se poderia encontrar um suporte para qualquer doutrina ou dogma, indicando em seu lugar um sistema aberto sem verdades definitivas e adaptado ao zeitgeist moderno. De dogma, apenas a história, diria Harnack; de Jesus, apenas aquele criado pela igreja primitiva, não encarnado, o Cristo idealizado da fé!

A fusão entre cultura e religião, que a princípio exala coerência e ubiquação do evangelho no mundo, gestou, na verdade, uma espécie de sincretismo, no qual, realidades como filosofia e revelação, graça e ética estariam tão imiscuídas, a ponto de cada uma dessas realidades ficarem comprometidas em sua identidade. De certa forma, a síntese de todo esse liberalismo teológico protestante, construído em duzentos anos de pesquisa, (descontando os primeiros trabalhos críticos ainda no século XVII) foi magistralmente exposta nas conferências sobre a Essência do 
Cristianismo $^{35}$, proferidas por A. von $\mathrm{Harnack}^{36}$, que naquele momento era o principal pensador da teologia liberal. Não só os teólogos, mas os intelectuais em geral, tinham essa confiança na capacidade humana para a concórdia e a paz. Harnack fazia parte dessa Kulturprotestatismus elevada, ele "estava imbuído por uma fé otimista no progresso histórico, acreditava poder unir em harmonia quase indestrutível a religião e a cultura, a justiça divina e a ordem terrena, o trono e o altar"37.

A fé protestante, a partir do século XVII, firmemente ancorada nas Escrituras e em seus símbolos, confissões e catecismos de onde extraíra seu corpus doutrinal, percebeu cedo, a necessidade de articular esse entendimento confessional e espiritual com sua vida no mundo, com sua presença na sociedade humana. Não pretendia repetir o ethos católico medieval. Assim, o fenômeno protestante manifestou-se de forma criativa e diferenciada ocupando espaços da vida cotidiana, não apenas na educação, nas fábricas, no comércio, na saúde e alimentação, na navegação, na magistratura e descobertas científicas etc., senão também na luta pelos direitos sociais do indivíduo, pela melhoria das condições de trabalho, pela liberdade de consciência, exame e expressão, fazendo valer seu protesto como um direito dado por Deus diante do Estado ou mesmo da própria autoridade religiosa, direito ao corpo e à propriedade. Às duras penas, foi aprendendo a tolerância com a sua própria intolerância ${ }^{38}$. A luta pela democracia, sufrágio universal e separação de Igreja e Estado fez parte da agenda protestante. Entretanto, o grande desafio ainda estava distante. A prática escravagista e seu comércio hediondo negavam

${ }^{35}$ As conferências foram realizadas na Universidade de Berlim no inverno de 1889-1900 em encontros semanais com a assistência de centenas de ouvintes e tiveram uma grande repercussão no mundo teológico e intelectual da Alemanha e Europa. Foram publicadas imediatamente sob o título Das Wesen des Christentums. Leipzig, 1900. Em Português (tradução do Inglês: What is Christianity?), HARNACK, A. von. 0 que é cristianismo? São Paulo: Editora Reflexão, 2009.

${ }^{36}$ Sua principal obra: Lehrbuch Der Dogmengeschichte. 3 vols. Freiburg: J. C. B. Mohr, 1886-1890. Obra inigualável em erudição a respeito das origens do cristianismo, bem como do papel importantíssimo do Helenismo na formação da literatura, doutrina e ética cristãs.

${ }^{37}$ Tato, I. G. Verbete: “Barth, Karl“. In: Xavier Pikaza e Nereo Silanes (dirs.) Dicionário Teológico 0 Deus Cristão. São Paulo: Paulus, 1998.

${ }^{38} \mathrm{Um}$ grande contingente protestante permaneceu imobilizado no ambiente dogmático do confessionalismo sem abertura para o diálogo cultural ou ecumênico. Mutatis mutandis, as mazelas religiosas tão comuns nos tempos medievais, foram recorrentes no universo reformado. 
princípios da própria Escritura, era o maior escândalo a ser vencido o que só foi possível pela obstinação cristã de pessoas e movimentos, atualizando a mensagem profética das Escrituras somada ao Evangelho inclusivo de amor e misericórdia de Jesus Cristo. Quakers, Levellers, Não-conformistas, Metodistas, J. Woolman, S. Sharpe, J. Wesley, W. Wilberforce, T. Clarkson e tantos mais, por entenderem a fé como uma ação libertadora, defenderam uma sociedade cidadã presente em cada indivíduo, evocaram o direito natural de seus antecessores (H. Grotius, S. Pufendorf etc.). Exigiram igualdade de tratamento, educação para todos, educação básica e universitária inclusive para mulheres e crianças.

\section{Nova Teologia Protestante e Ecumenismo (1919 em diante)}

A nova teologia protestante se afirmou, de um lado, contra o espírito reducionista reinante tanto no liberalismo teológico que negava o caráter transcendente da mensagem cristã, considerando-a apenas do ponto de vista moral, sob a influência do Iluminismo de Kant, quanto no fundamentalismo que ignorava a realidade do cristianismo e das Escrituras como produtos humanos de comunidades de fé, advogando uma espécie de sobrenaturalismo cego que desprezava as interações histórico-culturais das origens judaico-cristãs e dos textos sagrados. De outro, ela propunha uma aproximação ecumênica das tradições cristãs, como sendo a contribuição cristã para a construção de uma nova sociedade e de uma cultura de paz mundial, especialmente após os conflitos da Primeira Guerra Mundial.

Mesmo antes da publicação da obra que daria início a esta nova teologia - Comentário da Epístola aos Romanos, de Karl Barth em 19199, vários setores do protestantismo, já na segunda metade do século XVIII e durante todo o século XIX, buscavam encontrar seu caminho, destino e vocação não mais apenas na identidade doutrinária, mas no diálogo ecumênico, ainda que incipiente. Walter Rauschenbush (1861-1918),

${ }^{39}$ Em Português: BARTH, K. A carta aos Romanos. São Leopoldo/EST, 2016. 
sintetizou esses esforços com sua Teologia do Evangelho Social ${ }^{40}$. Esta nova teologia protestante foi responsável pela renovação do próprio protestantismo, por meio de uma produção teológica significativa. Pensadores como K. Barth, R. Bultmann, E. Brunner, M. Niemoler, F. Gogarten, P. Tillich, trouxeram à tona, o caráter dialético da teologia. Posteriormente, Barth e outros se posicionaram politicamente e produziram a Declaração de Barmen $^{41}$, em relação ao domínio nazista na igreja e na sociedade. O. Cullman e W. Pannenberg, recuperaram a dimensão histórica da revelação de Deus ${ }^{42}$. D. Bonhoeffer, da cela de seu cárcere, chocou o mundo cristão com suas Cartas da Prisão ${ }^{43}$, revelando a relação entre cristianismo e a secularização de um mundo tornado adulto - agir Etsi deus non daretur - "Como se deus não existisse" (Carta 177). Discípulos de Bultmann e outros, como E. Käsemann, E. Fuchs, G. Ebeling, J. Jeremias, G. Bornkamm indicaram novos caminhos hermenêuticos para a teologia, inclusive para a polêmica do Jesus Histórico que em Bultmann ficara estagnada. P. Tillich, entre outros desafios, abriu de vez as portas da teologia ao propor uma correlatio entre o mundo da fé e a cultura. Theology of Culture (1959) ${ }^{44}$ representa precisamente esse momento do

${ }^{40}$ A theology for the social gospel. New York: The Macmillan Company, 1918; Cristianizing the social order. New York: The Macmillan Company, 1926; The social principles of Jesus. New York: Association Press, 1916; Christianity and the social crisis. New York: The Macmillan Company, 1920.

${ }^{41}$ Die Thesen der Barmer Erklärung - Declaração Teológica de Barmen - Um apelo às congregações evangélicas e aos cristãos na Alemanha em 31 de maio de 1934. Disponível em: <http://www.luteranos.com.br/textos/ a-declaracao-teologica-de-barmen>. Ver ainda: Helmut Renders. “Compromisso pastoral, clareza teológica e cidadania: a Declaração Teológica de Barmen como resultado de uma interação entre Igreja e academia teológica". Revista Caminhando v. 14, n. 2, p. 109-128, São Bernardo: UMESP, jul./dez. 2009, p. 109-128.

${ }^{42}$ Sobre o conceito de Heilgeschichte - História da Salvação em Cullmann e seu pensamento em geral, recomendo: PIKAZA, X. Dios y el tempo: El pensamiento de Oscar Cullmann. Barcelona: Editorial CLIE, 2014; Para adentrar na teologia de Pannenberg, indico PANNENBERG, W. et alii. La Revelación como historia. Salamanca: Sígueme, 1977; M. Fraijó. El sentido de la historia. Introducción al pensamiento de W. Pannenberg. Madrid: Ediciones Cristiandad, 1986.

${ }^{43}$ BONHOEFFER, D. Widerstand und Ergebung. Briefe und Aufzeichnungen aus der Haft - "Resistência e Submissão" (1951). Indico a excelente tradução brasileira (Nélio Schneider): Resistência e submissão: cartas e anotações escritas na prisão. São Leopoldo: Sinodal/EST, 2003, p. 487.

${ }^{44}$ Em Português: Paul Tillich. Teologia da cultura. São Paulo: Fonte Editorial, 2009. 
qual participou também, Reinhold Niebuhr ${ }^{45}$ e suas propostas de um socialismo cristão. J. Moltmann talvez simbolize o ápice desta nova teologia protestante no século XX. A ideia de uma "teologia engajada" neste saeculum, histórica, social, politizada e cultural, todavia, carecia de um sólido referente do universo teológico clássico, ainda que em nova abordagem. O teólogo que priorizou tal desafio foi o pastor e professor alemão, Jürgen Moltmann ${ }^{46}$. Para tanto, se utilizou do conceito cristão de esperança como categoria inerente da realidade mundana e presente na história e sociedade humanas e não apenas como uma dimensão transcendente ligada ao futuro. Como não poderia deixar de ser, nesses "novos ventos" da teologia, o pensamento de Moltmann é fruto direto de sua experiência existencial.

Outra frente do protestantismo foi a prática ecumênica. O objetivo não era outro senão o de refletir sobre de que forma os sentimentos e práticas religiosas, a fé e a crença, poderiam cooperar para a harmonia e amizade entre os povos e a coesão social. Nos espíritos mais devotos e sensibilizados na piedade protestante ecoava forte, entre outras, as palavras de Jesus no Evangelho:

E não rogo somente por estes, mas também por aqueles que pela tua palavra hão de crer em mim; Para que todos sejam um, como tu, ó Pai, o és em mim, e eu em ti; que também eles sejam um em nós, para que o mundo creia que tu me enviaste. E eu dei-lhes a glória que a mim me deste, para que sejam um, como nós somos um (João 17, 20-22).

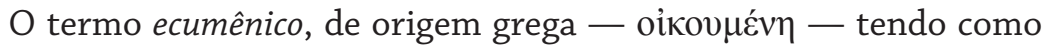
raiz o vocábulo Oikos = Casa, com o significado literal de "casa habitada", no vocabulário do cristianismo passou a ter o sentido de "mundo

${ }^{45}$ Duas de suas obras representam essa renovação da teologia protestante: Moral Man and Immoral Society (1932) e The Nature and Destiny of Man (1943) esse último, em dois volumes e tido como um dos maiores best-sellers da área de teologia norte-americana, aproximando o pensamento da Reforma com o patrimônio do Renascimento.

${ }^{46}$ Sobre o pensamento de Moltmann, indico: BAUCKHAM, R. The theology of Jürgen Moltmann. Edinburg: T\&T Clarck, 1995; Douglas M. Meeks. Origins of the theology of hope. Philadelpphia: Fortress Press, 1974; Maria C. L. Bingemer. "O Deus desarmado. A Teologia da Cruz de J. Moltmann e seu impacto na Teologia Católica". Estudos de Religião, v. 23, n. 36, 230-248, jan./jun. 2009. Disponível em: <https://www.metodista.br/ revistas/revistas-ims/index.php/ER/article/viewFile/884/939>. 
habitado", "lugar civilizado de morada", exatamente por ser presente do amor de Deus e por isso mesmo, objeto a ser alcançado com a mensagem cristã. Daí, deve haver uma identificação estreita entre ecumenismo e ação missionária. Devido ao expansionismo colonial e mesmo antes dele, no caso católico, missionários foram se instalando em centenas de campos de missão, cidades, vilas, lugarejos, aldeias e países inteiros ainda não cristianizados. Com certeza a atividade missionária ajudou na criação da ideia de ecumenicidade, uma vez que, diante das adversidades em lugares inóspitos ou hostis ao cristianismo, era preciso a cooperação e um mínimo de concórdia, apesar das diferenças doutrinais ou teológicas que se levava junto à mensagem do Evangelho.

As ações missionárias eram também ações urbanas aos empobrecidos, mendigos, desempregados das grandes cidades. Para essa cooperação, foi bem importante a noção de Reino de Deus, como uma dimensão superior ao espectro denominacional, tarefa árdua, pois, muitas denominações tornaram-se autossuficientes e a adesão a um conceito de Reino de Deus com prerrogativas, para muitas lideranças, era complexa, implicando em "ceder espaço". Aliás, em um belo texto sobre o ecumenismo ${ }^{47}$, o professor Zwinglio M. Dias, incansável nas lides ecumênicas, faz um eloquente lamento pela divisão e quebra da unidade, evocando Lutero e Melanchthon, mencionados por L. Febvre em seu clássico Lutero, um destino e Karl Barth, em sua monumental Dogmática da Igreja, recordado por Júlio de Santana.

Sinais de mudança surgiam pelo fato de metodistas, luteranos, anglicanos, congregacionalistas, valdenses, presbiterianos, batistas, etc., pela primeira vez se unirem em torno de uma tarefa comum, precisamente por aceitarem que a expansão do Reino de Deus detinha a primazia. No final do século XVIII e durante todo o século XIX a ideia ecumênica desenvolveu-se, tornando-se parte do vocabulário de diversas igrejas do protestantismo histórico, incluída na agenda pastoral e diaconal das várias igrejas. Por isso mesmo, o movimento ecumênico

47 DIAS, Z. M. “O Movimento Ecumênico: História e Significado”, p. 128-129 Disponível em: <https://numen. ufj.emnuvens.com.br/numen/article/viewFile/899/781>. 
moderno $^{48}$ teve o seu embrião e primeiros desenvolvimentos em solo protestante. Antes da criação oficial do CMI, os esforços, e desejos de unidade cristã foram traduzidos em congressos e conferencias mundiais que conseguiram, a partir de 1910, reunir um número cada vez mais representativo de cristãos de todos os continentes, dos mais variados contextos e tradições, incluindo os irmãos ortodoxos e posteriormente, após o Concílio do Vaticano na década de 60, também a presença dos irmãos católicos-romanos. Além da unidade da igreja, as temáticas diziam respeito a missão, o evangelismo e a ordem social. A Conferência Missionária Mundial de Edimburgo (1910) e o Congresso do Panamá (1916) ficaram restritos ao tema missionário, sem conotações ecumênicas, mas foram importantes para se dimensionar o potencial de articulação do protestantismo ao redor do mundo, além de reforçar a importância da unidade na ação e manter uma secretaria permanente para esse tema. O Congresso do Panamá foi uma reação pelo fato de Edimburgo não ter tratado a América Latina um campo missionário ${ }^{49}$, considerando-a já cristianizada pelo catolicismo. Essa iniciativa veio de lideranças missionárias norte-americanas instaladas em solo latinoamericano com a nomeação de um Conselho Missionário Internacional, responsável pelas futuras conferências sobre missão e unidade.

A Conferência Lambeth de 1920 adotou a base doutrinal episcopal ${ }^{50}$ e, entre vários documentos, emitiu o "Apelo a todos os cristãos", conclamando-os a caminharem em direção de uma união visível. Simultaneamente, tem-se o surgimento de organizações leigas

48 Para introdução ao tema do ecumenismo, indico: VISSER'T HOOFT, W. A. The ten formative years. Geneva: World Council of Churches, 1948; R. Rouse e S. Neil. A history of ecumenical movement: 1517-1948. London/Philadelphia: S.P.C.K/Westminster Press, 1954; Norman Goodall. El movimiento ecuménico: Qué es y para que trabaja? Buenos Aires: La Aurora, 1970; Harold E. Fey. A history of the ecumenical movement. Volume 2, 1948-1968: ecumenical advance. Philadelphia: Westminster Press, 1970; W. M. Horton. Christian theology: An ecumenical approach. New York: Harper, 1955; E. Duff. The social thought of the world council of churches. New York Association Press, 1956; Antonio G. Mendonça. “0 movimento ecumênico no século XX - algumas observações sobre suas origens e contradições". Disponível em: <http://www.koinonia.org.br/ tpdigital/detalhes.asp?cod_artigo=236\&cod_boletim=13\&tipo=Artigo> .

${ }^{49}$ Ver DIAS, op. cit., p. 135.

${ }^{50}$ Documento conhecido como Quadrilátero de Lambeth-Chicago oriundo da Câmara dos Bispos da Igreja Episcopal Americana de 1886 em Chicago e adotada em 1888 e reafirmada em Lambeth. 
cristãs, como sociedades missionárias, sociedades bíblicas, ACM, Federação de Estudantes Cristãos etc. No início do século XX, anglicanos também promoveram encontros específicos para oração pela unidade cristã. Igualmente, em 1920, na cidade de Genebra, 15 países se fizeram representar por meio de quase uma centena de delegados para uma conferência sobre "Cristianismo Prático", que em seu momento deu origem ao Movimento Life and Work - "Vida e Ação", concretizado cinco anos mais tarde na Suécia. O movimento anglicano Faith and Order — "Fé e Ordem" se reuniu na Suíça pouco depois. Foram esforços notáveis em prol de uma unidade perdida ou esquecida, buscando mitigar o escândalo da divisão cristã, especialmente marcante no protestantismo. Na sequência, foram realizadas as conferências em Estocolmo (1925), Lausanne (1927), Jerusalém (1928), Oxford e Edimburgo (1937), Madras e Utrecht (1938). Todas elas, de certa forma preparatórias, nas quais despontaram fortes lideranças na condução do ideal ecumênico.

Como se sabe, a criação do CMI - Conselho Mundial de Igrejas (WCC na sigla inglesa), deu-se em 1948, amalgamando toda essa caminhada de esperança e expectativa pela unidade da igreja. Ficou bem evidente na Assembleia de Amsterdã de criação do CMI, com a presença de 147 igrejas e 351 delegados provenientes da Europa e América do Norte, a preocupação com a ordem social, uma vez que nos encontros preparatórios essa questão foi exaustivamente debatida, como por exemplo em Oxford (1937), Londres (1946) e Bossey (1947), departamentos que discutiram as questões sociais à luz da Bíblia. Dessa maneira, a criação do CMI significou que dezenas de igrejas entraram formalmente do diálogo ecumênico e, com isso ficaram manifestas as divergências de opiniões, não apenas em temas doutrinários e dogmáticos, mas também ao redor da questão ética. Por isso, fez-se necessária a elaboração de uma filosofia social que pudesse enfrentar as questões práticas, partindo da ideia de uma lei natural dada por Deus para a conduta humana, bem como a razão como uma forma adequada de apreender a verdade moral ${ }^{51}$. Era uma situação bem complexa levando-se em conta as concepções diferentes nos membros do CMI acerca da natureza

51 DUFF, E. The social thought of the World Council of Churches. New York: Association Press, p. 96, 1956.

Rev. Pistis Prax., Teol. Pastor., Curitiba, v. 9, n. 2, 441-463, maio/ago. 2017 
humana o que afetava diretamente o tipo de relação que a fé cristã poderia ou deveria estabelecer com a ordem social.

Após Amsterdã, o CMI realizou uma sequência de Assembleias ${ }^{52}$ nos anos que se seguiram: Evanston (USA, 1954), Nova Delhi (Índia, 1961), Uppsala (Suécia, 1968), Nairobi (Quênia, 1975), Vancouver (Canadá, 1983), Canberra (Austrália, 1991), Harare (Zimbabwe, 1998), Porto Alegre (Brasil, 2006), Busan (Coreia do Sul, 2013). O CMI, com sede em Genebra na Suíça, conta hoje com 348 igrejas membros, representando um total de mais de 500 milhões de cristãos de todas as regiões do mundo. Certamente a maior de todas as contribuições do CMI tenha sido a de abrir o caminho para o diálogo ecumênico, sugerindo igualmente, a necessidade do diálogo inter-religioso.

\section{Considerações finais}

Após esta sintética narrativa, não é difícil a percepção de que o fenômeno protestante, em seus inícios, foi uma aventura, uma vez que esteve longe de ser um empreendimento programático. Não se podia sequer imaginar que o protesto de um monge alemão na distante Saxônia pudesse reunir e articular desejos contidos por toda a Europa cristã. O fato é que houve uma convergência de ideais, desencadeando diversos movimentos de cunho reformista e cismático. Tornou-se impossível um controle, dado que o espírito revolucionário foi parte integrante da novidade trazida pela Reforma. O Protestantismo é, de fato, um caso típico, no qual a realidade multifacetária nos impede qualquer abordagem em tons definitivos, precisamente pelo caráter de transitoriedade em seus valores e crenças e câmbios bruscos e recorrentes em seu modus operandi, as definições são datadas com rapidez ou se acomodam em interpretações particulares; além é claro, daquelas dificuldades historiográficas naturais. Não por acaso um de seus lemas centrais seja: Ecclesia semper reformanda est. De qualquer modo, há que se registrar que se o cristianismo foi fundamental para a história do

52 Para detalhes das temáticas abordadas em cada Assembleia, estrutura organizacional, relação de igrejas membros, regiões, arquivo, biblioteca etc., ver Site do CMl: <https://www.oikoumene.org/es>. 
Ocidente, o protestantismo teve uma parcela significativa nessa mudança de paradigma ocasionando o surgimento da sociedade moderna.

\section{Referências}

BAUMAN, Z. Em busca da política. Rio de Janeiro: Zahar, 2000.

BOBBIO, N. Liberalismo e democracia. São Paulo: Brasiliense, 2005.

COLLINSON, P. A reforma. Rio de Janeiro: Objetiva, 2006.

DELUMEAU, J. Nascimento e afirmação da reforma. São Paulo: Pioneira, 1989.

DIAS, Z. M. "O Movimento Ecumênico: História e Significado”. Numen: revista de estudos e pesquisa da religião, Juiz de Fora, v. I, n. 1, p. 127-163, 1998. Disponível em: 〈https://numen.uff.emnuvens.com.br/numen/article/viewFile/899/781〉. Acesso em: $01 \mathrm{dez} .2016$.

DUFF, E. The social thought of the World Council of Churches. New York: Association Press, 1956.

GELLNER, E. Condições da liberdade: A sociedade civil e seus rivais. Rio de Janeiro: Jorge Zahar, 1996.

HABERMAS, J. Lo político: el sentido racional de una cuestionable herencia de la teología política. In: MENDIETA, E.; VANANTWERPEN, J. (Org.). El poder de la religión en la esfera pública. Madrid: Editorial Trotta, 2011.

HEGEL, G. W. F. Filosofia da história. Brasília: Editora UNB, 2008.

LUTERO, M. Os catecismos. Porto Alegre/São Leopoldo: Concórdia/Sinodal, 1983.

OBERMAN, H. A. Luther: man beteween God and the Devil. New Haven: Yale University Press, 1989.

OBERMAN, H. A. The impact of the reformation. Grand Rapids-MI-USA: Wm. B. Eerdmans Publishing Co., 1994.

RAWLS, J. O liberalismo político. Brasília: Inst. Teotônio Vilela e Ed. Ática, 2000. 
TATO, I. G. Verbete: "Barth, Karl“. In: Xavier Pikaza e Nereo Silanes (dirs.) Dicionário Teológico O Deus Cristão. São Paulo: Paulus, 1998.

TAYLOR, C. As fontes do self: A construção da identidade moderna. São Paulo: Loyola, 2013.

WALZER, M. Las esferas de la justicia: Una defensa del pluralismo y la igualdad. México: FCE, 1997.

WHITEHEAD, A. N. A ciência e o mundo moderno. São Paulo: Paulus, 2006.

Recebido: 07/01/2017

Received: 01/07/2017

Aprovado: 26/05/2017

Approved: 05/26/2017 
